\title{
Use of Some Available Plant Residues in New Valley as Alternative Litter Materials for Managing Broiler Chickens
}

\author{
Farghly M. F., A., M. I. El-Kelawy, A. Y. Kassab and A. M. Hashem \\ ${ }^{1}$ Dept. of Poultry Production, Fac. of Agric., Univ. of Assiut (71516), Egypt. \\ ${ }^{2}$ Dept. of Poultry Production, Fac. of Agric., Univ. of New Valley, Egypt
}

\begin{abstract}
This experiment carried out to determine the effects of using some alternative litter materials on the growth performance, litter conditions, airborne quality and health traits of broiler chickens, one hundred and eighty, 1 day old broiler chicks were reared for six weeks and housed in pens in six equal groups ( 3 replicates of 10 birds each). Wheat straw (control), wood shaving, rice hulls, corn stalks chips, chopped palm fiber and palm spines chips were used as litter materials in this the study. Wheat straw, wood shaving, rice hulls, corn stalks chips, chopped palm fiber and palm spines chips did not differ statistically for body weight, feed consumption, feed conversion ratio and survivability $(\mathrm{p}>0.05)$. However, body weight tended to increase on wood shaving and palm spines chips. Carcass weight and gizzard yield were significantly $(\mathrm{p}<0.001)$ higher for birds raised on corn stalks chips maintained approximately $10 \%$ lower moisture level in comparison to Wheat straw and wood shaving. The lowest bacterial counts and moisture content of used litter was found in corn stalks chips followed by palm spines chips, wood shaving, rice husk, wheat straw and chopped palm fiber. There was no statistically significant effect between type of litter on litter $\mathrm{pH}$, litter temperature and body conformations. Depends on the price and availability palm spines can be used as litter material instead of wood shaving and wheat straw. In conclusion, corn stalks chips, chopped palm fiber and palm spines chips can potentially be used as alternative litter materials in New Valley for growing broilers.
\end{abstract}

Key Words: litter materials growth performance, broiler chickens. 